\title{
Travels of a Salesman: From Brooklyn to Beijing
}

Dr. Essam Fattouh

Assistant professor in Department of English Language - Faculty of Arts Alexandria University 
Few playwrights of the past half century can have been as tirelessly analytical of their own work as the late Arthur Miller. In interviews with critics and journalists, in essays and introductions to his published plays - and most intensively, perhaps, in his autobiography Timebends (1987) - the playwright has examined his own work in searching detail. Often the scrutiny is directed to the solving of this or that technical problem of the dramatist's craft, or - notably in Timebends - to a defence of his work against an often hostile or uncomprehending critical reception. A further compelling interest for the playwright lies in a constant striving to grasp precisely what it is that has made his work a source of fascination to theatre goers outside the United States, even when it has been receiving an ambivalent critical reception at home. Miller's plays have been performed with acclaim to audiences in societies as diverse as those of Argentina, France, the Soviet Union and China - sometimes winning a more enthusiastic reception from the critics than in his native United States. As he explained in Timebends: 
When I looked back, it was obvious that aside from Death of a Salesman every one of my plays had originally met with a majority of bad, indifferent or sneering notices. Except for Brooks Atkinson at the beginning, and later Harold Clurman, I exist as a playwright without a major reviewer in my corner. It has been primarily actors and directors who have kept my work before the public, which indeed has reciprocated with its support. Only abroad and in some American places outside New York has criticism embraced my plays. ${ }^{1}$

By Miller's own account, the two plays that have been overwhelmingly popular overseas, are The Crucible (1953) and Death of a Salesman (1949). (London, in fact, saw a production of Death of a Salesman in 1950, probably the earliest performance of the play outside of the United States.) For this reason and also because Miller himself has written extensively about the reception of the latter work during the rehearsal and staging of an experimental version of the play in Beijing in the 1983 - the present study will concentrate on this play. Some of the most interesting, as well as the best-documented, reactions to Miller's work are to be found in his account of its reception in China, a society so apparently different from that of the 
United States, as to be worth detailed attention. It is therefore proposed to touch on productions of The Crucible and Death of a Salesman in Europe and the former Soviet Union, before moving to focus in detail on reactions to Miller's work in China. ${ }^{2}$

Miller himself has often alluded to - while at the same time expressing his contempt for - what he always viewed as the narrowness, shallowness and wholesale commercialism of the New York theatre scene ${ }^{3}$ - the lack of understanding, indifference, even hostility, to his work expressed by critics in the United States, especially in the Cold War decade of the 1950s. (It is indicative of the fear of being labelled 'leftist' in those years, that after Columbia Pictures made its 1951 film version of Death of a Salesman the author was confronted with a demand to allow all showings to be prefaced by a short feature film in which it was explained that Willy Loman was utterly untypical of the modern salesman - that in the modern world the profession was a noble and rewarding one. Miller had to threaten a lawsuit before the idea was dropped.) Even then, as he complained, the film's interpretation of his complex protagonist was a travesty, showing Willy Loman as virtually psychotic, therefore nullifying 
the play's social themes. As Miller pointed out, if Loman were "nuts," then "he could hardly stand as a comment on anything. It was as though Lear had never had real political power but had merely imagined he was King". 4

Miller's own perception that his work encountered universal misunderstanding can be over-emphasised. After all, at the very outset of his career, in the late 1940s and early 1950, parallel with the negative reactions of many critics he was simultaneously hailed as the rising star of a new and radical American theatre. In 1947 All My Sons, his first major success, received the New York Drama Critics' Circle Award and this in the face of audiences the playwright described drily as:

...impatient with long speeches, ignorant of any literary allusions whatever, as merciless to losers as the prizefights crowd and as craven to winners; an audience that heard the word culture and reached for its hat.... 5

In the year of its first production in 1949, Death of a Salesman was awarded both a second Drama Critics' Circle accolade, and the Pulitzer Prize for drama. Within a year of this first performance, moreover, the 
play was in performance in every major city of the United States. ${ }^{6}$

What remains the case, however, is that even when applauded by his most discerning critics, Miller has not always been well understood by the majority of his reviewers. The playwright himself vocally resented what he judged to be the baneful influence of the conservative New York Times, and the monopolistic influence its reviewers exercised over critical opinion across the East Coast:

For all intents and purposes the contemporary American [critical] repertoire comes out of New York and represents the taste of whoever is writing the New York Times review, only slightly mitigated by other reviews The Times did not invent the situation, but there it is, a dictatorship as effective as any cultural control mechanism in the world. ${ }^{7}$

Some of the negative critical views expressed in the early years give an indication of the level of incomprehension in influential quarters. Eleanor Clark, for instance, writing in the left-leaning Partisan Review a publication that might be expected to react sympathetically to Miller's work - in 1949 called Death of a Salesman a "hodge podge" of "dated materials and 
facile new ones," and "an intellectual muddle." ${ }^{8}$ For Clark the play moreover merited the epithets "clumsy," "pompous," "specious," and "flat." It was, in short, she wrote, "a very dull business, which departs in no way that is to its credit from the general mediocrity of our commercial theatre." 9

As Stephen Barker comments, in his comprehensive survey of Miller criticism,

Perhaps not surprisingly, given the nature of the expectations of American theatre audiences, Miller's critical reception, particularly in his native America, has been mixed, at times downright hostile. ${ }^{10}$

Miller has irked critics from the beginning of his career and continues to do so ... . ${ }^{11}$

One immediately apparent obstacle in America to a full appreciation of Miller's work - an obstacle noted by the playwright himself $-{ }^{12}$ is the play's overwhelmingly tragic vision, so clearly at odds with the relentless optimism of Hollywood cinema, or of the majority of Broadway musicals. (At the most obvious and superficial level one need only consider the grim dénouements of the best-known plays: in suicide (All My Sons, Death of a Salesman); manslaughter (A View from 
the Bridge); executions (The Crucible). In Miller's dramatic universe, things have a tendency to turn out badly. ${ }^{13}$ What Steven Centola refers to as Miller's "tragic vision" is "more compatible with the perspective of Europeans who accept human imperfection and recognize the need to offset it with responsible social action."14 (These points about the Millerian preoccupation with both 'social action' and with social responsibility will be returned to in due course.)

Much of the work by this second-generation immigrant member of a family with its roots in Eastern Europe is deeply grounded in European theatrical tradition in a whole variety of ways - beginning with the often-noted influence of Ibsen - and of European social drama generally - on Miller's early work and on All My Sons in particular. ${ }^{15}$ Although Miller claims that by the time of Death of a Salesman he was leaving the direct influence of Ibsen behind him, a more indirect legacy persists. One abiding element is surely the playwright's preoccupation with the consequences of past actions in the present. What fascinated him in the work of Ibsen as indeed in classical Greek tragedy - was, as Miller himself puts it, "the story of how the birds came home to roost." ${ }^{16}$ One need only think of Keller in All My 
Sons, whose guilty knowledge that he has sent young pilots to their deaths by manufacturing faulty aircraft is uncovered by his son; or the accumulated illusions of a lifetime that come to wreak their revenge on Willy Loman; or the tragic consequences of past marital unfaithfulness for John Proctor, protagonist of The Crucible, ${ }^{17}$ It is, moreover, precisely this sense of the past, and the burden of the past, that Miller claims American society has lost. Attempting to account for the greater appeal of his work in Europe he once went so far as to claim, "We don't have any past any more."18

At least four of Miller's plays deal with the influence of a European past on the present. A View from the Bridge deals with the world of newly-arrived Sicilian immigrants in New York, and the code of jealousy and family honour they carry with them from the old country. The Crucible - albeit with the purpose of casting light on and drawing parallels with a contemporary social issue - offers a representation of a period when New England settlers still felt themselves strongly linked to the values of a recently Puritan England. ${ }^{19}$ Incident at Vichy (1964) and Broken Glass (1994) both deal with the Nazi period in Europe (the latter also reminding its audiences of the all-too-human 
tendency to look away from atrocities in the world of the twenty-first century).

It is by reference to alleged "European" themes and preoccupations also that the British critic and reviewer Michael Billington accounts for the popularity of Miller's plays with British audiences. While he believes - rather questionably in my view - that Miller's "liberalism", his "apparent faith in human perfectability", actually links the plays more with an American intellectual tradition than with European pessimism and doubt, Billington adds that Miller possesses the belief of the European dramatist "in the need to ask daunting questions," rather than to "provide comforting answers."It is this questioning spirit, that, in Billington's view, makes Miller "such a fascinating writer: he remains totally anchored in American life while challenging almost all the values and beliefs that make that society tick." ${ }^{20}$ It is a view that Miller himself endorses, in an autobiographical comment made seven years later: "Great drama is great questions, or it is nothing but technique."21

Billington calls Miller "the late twentieth century's most eloquent critic of the devalued American dream." Arguably it is this critical scrutiny of American society, 
even more than the tragic sensibility or the affinities with an alien European tradition, that led to the sharp decline in the playwright's popularity, from as early as the 1950s. The challenge to complacent acceptance of the status quo that began with All My Sons found its flowering in Death of a Salesman in 1949. The author took it as a compliment when, on the play's opening night, an outraged member of that first audience angrily denounced it as "a time bomb under American capitalism." As Miller, writing with the hindsight of nearly thirty years, was to describe his intentions his work was aimed at "this pseudo life that thought to touch the clouds by standing on top of a refrigerator, waving a paid-up mortgage at the moon ...." In the same passage of Timebends the criticism broadens to embrace not only the consumerist values of an individual, but an entire social system. In the postwar world of the play's composition, "Europe was dying or dead, and I wanted to set before the new [American] captains and the so smugly confident kings the corpse of a believer."22

Unquestionably, though, the turning point for Miller's early reputation in America occurred when, in 1953 he took on a theme even more controversial than 
that of the dark side of the American Dream - the McCarthy -era persecution of alleged 'left-wing subversives' by the Congressional Un-American Affairs Committee. Intrigued and disturbed by that secular ritual of absolution-through-confession of association with known leftists, followed by obligatory public denunciation of colleagues and neighbours, Miller found, in the public courtroom confessions of the seventeenth-century Salem witch trials, a compelling parallel with contemporary events. ${ }^{23}$

Miller once said The Crucible was the play of which he "felt proudest," adding the bold claim that if he had not written it, the period of the McCarthy persecutions "would be unregistered in our literature on any popular level." What is undeniable is that by linking the seventeenth-century trials in Salem to the McCarthy purges in the mid-twentieth century Miller gave the new phrase, "witch hunt" to the political vocabulary, as the standard term for a paranoid campaign against a targeted minority.

The first New York production of The Crucible, in 1953, forced audiences to take sides. ${ }^{24}$ Some evidently found the play offensive. As Miller himself explains: 
What I had not quite bargained for ... was the hostility in the New York audience as the theme of the play was revealed; an invisible sheet of ice formed over their heads, thick enough to skate on. In the lobby at the end, people with whom I had some fairly close professional acquaintanceships passed me by as though I were invisible ... . ${ }^{25}$

On later nights, an opposite partisanship made itself apparent. On the night Ethel and Julius Rosenberg were executed for having supposedly sold atomic secrets to the Soviet Union (like John Proctor in The Crucible they could have saved their lives by pleading guilty and denouncing others), both audience and cast remained standing in the theatre at the end of the play, for a moment of respectful silence in their memory. With box office takings falling - to the point where the cast actually volunteered to go on playing without payment - the author made a decision. After the Rosenbergs' execution, his continuing to stage the play "became an act of resistance for them." Miller took over the direction of The Crucible himself, eventually bringing in a new cast, and a starkly simple stage setting. The play struggled on for a few more weeks, "but finally a sufficient audience was simply not 
there." Although a fringe production two years later ran for more than twenty months, the play had failed with the theatrical and literary establishment.

In 1954 Miller was refused a passport to attend the first performance of The Crucible in Belgium. In 1955 he was dropped from work on a public service film script for the Youth Board of New York City, because of his liberal-left views. Finally, the playwright was himself summoned before the House Un-American Affairs Committee and directed to 'name names. ${ }^{26}$ As he writes in Timebends, "I was growing more and more frighteningly isolated, in life as in the theatre. ${ }^{27}$

It then became fashionable in the United States to disparage Miller's works on aesthetic grounds - a rejection from which the playwright's reputation in America took decades to recover. The Crucible in particular - it was rapidly becoming a staple of amateur and repertory theatres across Britain - was not performed again on the East Coast until 1973 - and then not on Broadway, but in Philadelphia. It was not until 1975, a full twenty -two years after its first performance, that The Crucible was again produced in New York. Meanwhile, as Miller happily remarks in Timebends, British directors and audiences appreciated 
and sensitively interpreted his work. He reserves particular praise for Laurence Olivier's 1965 London production of The Crucible, in which Colin Blakely played Proctor. The description in Timebends seems worth quoting at length:

What I would not forget was a long silence at the beginning of the second act when Proctor enters his farmhouse and washes up and sits down for dinner. It must have lasted many minutes as Elizabeth served him and then went about her chores, the absence of speech itself the proof of their hurt pride, their anger with one another, and somehow their mutual regard too, and at the same time it drew the mounting fear of what was happening in Salem Town into their house. From such exactness, what passion! ${ }^{28}$

Official persecution by his own government only served to enhance Miller's reputation elsewhere in the world. In the partisan and divided cultural climate of the Cold War his plays were enthusiastically received not only by Western European intellectuals wishing to distance themselves from the perceived excesses of Cold War ideology, but by writers and critics in the thencommunist Soviet Union and China who saw in the American state's hounding of a major American 
dramatist a useful weapon in the ongoing propaganda battle with the West.

While its author was still the subject of establishment disapproval in his native land, The Crucible was received enthusiastically in Britain, France, Argentina and the Soviet Union. It was first produced in Belgium in 1953 (the première that Miller notoriously was denied a passport to attend). In 1957 a Franco-German company made a very freely adapted film version, directed by Raymond Rouleau and starring Simone Signoret and Yves Montand. The film was based on an earlier theatrical production, with a script by Jean-Paul Sartre, transferring the play's setting from Puritan New England to Catholic Brittany (and, incidentally, laying what Miller thought undue emphasis on a theme of class struggle quite absent from the original text). ${ }^{29}$ The play became a staple of the British theatrical repertoire. In the 1980s it enjoyed a resurgence at major national theatres, with Bill Bryden's version at the Comedy Theatre, London (1981), David Thacker's at The Young Vic (1986), the RSC productions of 1986 and 1989, and a further production at the National Theatre in 1990. 
For Miller - who for many years was a committed and caring President of PEN, the international organisation for defending writers' civil liberties - The Crucible came to have particular significance as a social barometer. As he wrote in Timebends, "I can almost tell what the particular situation in a country is when the play is suddenly a hit there - it is either a warning of tyranny on the way or reminder of tyranny just past." When in 1986 the Royal Shakespeare Company took a production of The Crucible to Poland, Miller records that a number of high-ranking members of the government sat in the audience, by their presence, the author believed, "urging on its message of resistance to a tyranny they were forced to serve." During his visits to China in the1980s in the very recent wake of the excesses of the Cultural Revolution, many people told Miller how the play for them spoke of their own experiences during that turbulent period - decades when, as he put it, "accusation and enforced guilt ruled China and all but destroyed the last signs of intelligent life." He discussed The Crucible with the writer Nien Cheng, who had suffered as "an enemy of the people" during the Cultural Revolution. Nien Cheng "could not believe that a non-Chinese had written the play," 
finding the twisted logic of the inquisitors in The Crucible so similar to that she had encountered in her own experience. Miller adds - alluding to the violent chaos unleashed by the young Red Guards, so similar to the instigating role played by the hysterical and manipulative young women in his play - "It was chilling to realize what had never occurred to me until she mentioned it - that the tyranny of teenagers was almost identical in both instances." ${ }^{31}$

It was not only the author who followed the fortunes of The Crucible, reading it as an index of tyranny, and of political paranoia, Critics in more recent times have drawn analogies between the play and twenty-first century events. The British reviewer Michael Billington, for instance, writing in The Guardian in 2008 about a new London production, saw in this play of the McCarthy era "a dire warning about declaring war on unknown forces." ${ }^{32}$ Richard Eyre, reviewing a New York production for The Guardian six years earlier, had already found in President George Bush's "You are either with us or against us," an eerie and chilling echo of Judge Danforth's words to Francis Nurse, "A person is either with this court or he must be counted against it, there be no road in between., 33 
Throughout his career Miller kept a close analytical eye on the critical reception of his work outside of the United States. Reactions to his plays in other cultures were a source of endless fascination to him. As he observed,

I often learned something about the state of the world's mind through the various receptions of my plays, and new perspectives about our theatre have come from the past thirty years of travel. ${ }^{34}$

Since its first performance, according to Brenda Murphy, "there has never been a time when Death of a Salesman was not being performed somewhere in the world." $" 35$ In an interview he gave in the late 1980s Miller addresses the question of the play's phenomenal international appeal:

It seems to catch the paradoxes of being alive in a technological civilization. In one way or another, different kinds of people, different classes of people, apparently feel that they're in the play ... . It seems to have more or less the same effect everywhere there is a dominating technology. Although it's popular in places where life is far more pretechnological. Maybe it involves some of the most rudimentary elements in the civilizing process: family cohesion, death and dying, parricide, rebirth, and so on. The elements, I guess, are rather fundamental. People feel these themes no matter where they are. 
It is somewhat surprising to find Miller ascribing the widespread international appeal of his play not to any critique of consumer capitalism but to the worldwide spread of "technology" - though when he alludes to the compelling human themes dramatized by the play, he might seem to be on firmer ground.

As already mentioned, he enjoyed the appreciative reception given Salesman, as he always refers to it, in London. If one is to believe his observations in Timebends, the discerning response of British audiences, and the diverse and mainly positive critical reviews, struck him as blessedly far from the perceived tyranny of the New York Times. Far more challenging and intriguing, however, was the treatment his plays received in Russia and China, until the late 1980s wedded to aesthetic and socio-political ideals very different from those of either Western Europe or the United States. The subject of Miller's reception in these communist societies is one I now propose to explore in general terms, before moving on to a detailed consideration of Chinese reactions to Miller's own ground-breaking production of Death of a Salesman in Beijing. 
With his wife, the linguistically gifted Germanborn photographer Inge Morath, Miller travelled in Russia in the late 1960s. One outcome of their journey was his candid, often very perceptive, meditation on literature and society, In Russia (1969). Miller found himself at once engaged and repelled by many aspects of Soviet society. With characteristic even-handedness he strove to find what was valuable and enduring in a state culture that at every turn denied his most cherished values of literary independence and freedom of expression. There was, he wrote

a profound grandeur here, like a sphinx, a human construct of devotion and endurance, forced obedience and genuine communal conscience, that is finally with all its failings a sublime attempt to create a condition of selfrespect in a culture that was always cursed with master-slave relationships.

"Whatever epithets Russia has ever deserved," Miller adds, "trivial is not one of them." ${ }^{, 37} \mathrm{He}$ could hardly fail to recognise, either, the respect, amounting almost to reverence, that Russian society paid its literature and its literary artists. It impressed him that during the Nazi invasion of Russia in the Second World War the Soviet government had arranged for the entire 
contents of Tolstoy's house to be stored in hiding. Would the US government have reacted similarly in time of crisis to save the historic personal effects of an American writer? Miller doubts it. ${ }^{38}$ In the particular attachment to the memory of Tolstoy he perceives more than mere nostalgia for tradition. In the Soviets' virtual "idolatry", as he terms it, of Tolstoy, Miller detects "an expression of their final, unadmitted wish to keep alive the rule by which they may be corrected one day, for the purpose of literature can only be to tell the truth., ${ }^{39}$

As a writer whose own work had been damned with faint praise or simply ignored by his fellow citizens at home, Miller found himself especially challenged by his encounters with those dissident writers and artists of the period, who went on producing work disapproved of - whether for its form or its content - by the Soviet state. It is almost with envy that he writes of the peculiar position of such artists, contrasting it with that of the writer in the West:

In the West, where everything in art is allowed, the artists feel unneeded by society, supercargo. Here, the repression is a mark of art's importance, otherwise why would government bother policing it? In which setting is the artist closer to reality ${ }^{40}$ 
Hardly surprisingly, no doubt, such views were not welcome to Soviet officialdom. Upon publication of In Russia all Miller's works were banned in the Soviet Union for several years.

Miller defended the Russian theatre of the period against Western charges that the theatre in Russia was "stale". The Soviets might, he wrote, have excluded and suppressed the theatre of the Absurd, but still he found much to commend in contemporary Russian production values. There was, he claimed, "very little in the West" that could "match the vitality of the best Russian productions" which would, he believed, "be of first importance anywhere." These he found to be "highly finished and complete, yet imaginative and sometimes wild." He also praised the vitality and professionalism of Russian actors and the enthusiasm and discernment of Russian audiences. For anything innovative or original, he wrote,

There is almost an atmosphere of adoration in the house, an open gratitude to the author, the actors, the director. It is as though there were still a sort of community in this country, for the feeling transcends mere admiration for professionals doing their work well. It is as though art were a communal utterance, a kind of speech which everyone present is delivering together. 
Less admirable, though, the playwright found, was what Soviet directors made of his own plays in production. He was irritated by attending a 1965 production of $A$ View from the Bridge, for instance, in which the script had been clumsily altered. What should be a gradual revelation of Eddie's repressed incestuous desire for his niece is crudely blurted out in the very first scene. Miller admired the quality of the acting in this production, but not the heavy-handed tampering with his text: "It was," he said, "almost like Oedipus turning to Jocasta in the first moments of the play and saying, 'It's no good being married to you, Mother ..."' When the playwright complained about the changes to his text, "We are not interested in all that psychology," he was told. ${ }^{42}$

In the case of Death of a Salesman - a play, as one might expect, greatly admired in Russia during the Soviet era - it would be tempting to assume that no such conceptual conflict would arise. In the words of Matthew Roudané:

The play exposes, for ideologues, the inadequacies of bourgeois America. This at least was the dominant view expressed by critics after the play's successful runs at the Pushkin Theatre in Leningrad and the Vakhtangov Theatre in Moscow during the summer of $19599^{43}$ 
In fact - though Roudané repudiates this particular reading of the play - in the process of doing so he gives a remarkably eloquent, and quite compelling, exposition of such an anti-capitalist interpretation:

Death of a Salesman, many critics suggest, is a critique of a capitalist society that brutalizes the unsuccessful. In Marxist terms, Willy completes the brutalization process by reducing himself to a commodity, an object, a thing, which enables him to make the greatest and last sale of his entire professional life: the sale of his existence for the insurance payment. ${ }^{44}$

While the play is clearly more complex and psychologically nuanced than the above summary would suggest, one need only recall the author's delight at the "time bomb under American capitalism" charge of one of its first spectators, to see where his own conception of the text and that of Soviet critics might arrive on common ground. What Miller objected to in Soviet productions of his work was not the foregrounding of the play's social message, but the crudity of characterisation: 
I was glad to know that Death of a Salesman had been produced, but my pleasure was greatly diminished by the news that it had been severely changed. Willy had been caricatured as a total fool, and Charley, who offers him financial help was rewritten and acted as a clownish idiot, since as a businessman he could not possibly be even slightly altruistic or have a shred of sincerity.

What the author did greatly value, on the other hand, was the appreciation, the "almost prayerful attention," as he called it, that Russian audiences gave his plays. As Miller explains, although the press and even the content and style of works of fiction were rigidly controlled, it was in the theatre during the Soviet period "that people found the most ample room for their spontaneous, unhampered insight and emotion." 45

Among all Miller's international audiences, those who might be expected to find Western theatre most culturally challenging were to be found in China. Miller made two extended visits to China within a few years of one another, in 1978 and again in 1983, when he was invited to direct his play in Beijing with a cast of leading Chinese actors. The play would be performed in Chinese, with Miller directing the actors at rehearsal through an interpreter. Ying Ruocheng, the actor who 
was to play Willy and who translated Death of a Salesman into Chinese, and Liu Housheng, General Secretary of the Chinese Dramatists Association, regarded this production as of crucial importance for the future of the theatre in China. Chinese society was slowly emerging from the trauma of the years of the Cultural Revolution, when theatres had been closed and actors sent to the countryside "to learn from the peasants." Writers had been harassed and harangued, jailed and sometimes even murdered. Mao tse Tung's wife Jiang Qing had seized effective control of power, and as a former actress considered it her prerogative to declare that only eight 'Permissible Plays' might be performed throughout China. Not surprisingly, Chinese theatre had stagnated and dwindled during the years of Jiang's de facto reign. Theatre director and translator alike hoped that the performance of a play from the West, with its - for Chinese theatre - radical approach to staging, flashbacks and stream-ofconsciousness, might open minds to new possibilities, and act as a catalyst for renewed dramatic creativity.

As Miller explained with reference to his first visit to China - but in words that might well apply to his later visit also - he and Inge Morath arrived in the 
country at the very moment when the Chinese people had witnessed the collapse of the temple of the orthodoxies of the Cultural Revolution:

when the faithful were emerging from the fallen temple with blinking eyes, trying to make out ordinary objects in the no longer charmed unearthly light of ordinary days ... Here then, is a bit of how it was to two people, well disposed, and trying to see and listen, at the particular moment when the dust of the temple began to settle. ${ }^{46}$

Miller's play was chosen, no doubt, not only for its perceived radical form, but also for its implicit critique of consumer capitalism. In the rapidly changing socioeconomic context of a China that was even then opening up markets both internally and to the wider world in preparation for a major economic take-off, the play was inevitably interpreted and misinterpreted in unexpected ways. Even on his first visit, Miller saw the "open surprise and mystification" in the eyes of a group of Chinese intellectuals as he tried to explain one theme of his play - how Americans "can't find any meaning in existence," since "material wealth has not brought them the happiness they thought it would." The playwright stopped short at this point in his explanation: 
"I realized I was talking to a man who did not have access to a bathtub and the absurdity of what I had to say was suddenly stunning." 47 No wonder a member of the audience on the opening night of Death of a Salesman in Beijing in1983 startled Miller, as the young man was overheard in the theatre lobby, talking about the play to a US television interviewer: "We are moved by it because we also want to be number one, and to be rich and successful." Miller comments ironically that he had had no idea, when he sat writing the play in the United States back in 1948, "that I was sending a message of resurgent individualism to the China of 1983 especially when the revolution had signified, it seemed at the time, the long-awaited rule of reason and the historic ending of chaotic egocentricity and selfish aggrandisement." 48

Other potential for cross-cultural misunderstanding arose from traditional Chinese values - the low esteem, in both Marxist and Confucian thought, in which the merchant or trader had long been held - so that, for instance, a salesman would be relegated to the "very lowest Confucian category of worth." gaps were closing, owing to the rise of consumerism in China - by 1983 it apparently was possible to buy a 
refrigerator on the instalment plan, for example rendering comprehensible Willy Loman's complaint that the refrigerator has worn out just as he has finished paying for it. $^{50}$ Though it was becoming possible to insure some valuable goods, however, the concept of life insurance was still largely unknown, and this pivotal element of the plot of Death of a Salesman would require explanation in a programme note. ${ }^{51}$ And to the end of rehearsals Miller and his cast would wrestle with a central paradox of his play: "Willy is desperate, yet he owns a refrigerator, a car, his own house, and is willing to 'settle' for sixty dollars a week!... This, in China, is nothing short of fantasy."

Inevitably, however well the play was translated into Chinese, the audience's lack of acquaintance with consumer capitalism meant they were likely to miss the ironic subtext in much of the dialogue. For example when Willy's wife Linda is trying to encourage her husband who has returned exhausted from his fruitless sales trip, she offers him a "new kind of American-type cheese." "It's whipped," she adds of this patriotic cheese, in language straight from the terminology of advertising. ${ }^{53}$ One might wonder, likewise, how many people in a society unfamiliar with name branding and 
commercial 'hype', would grasp the ironic significance of Linda's naive reply to Willy's complaint that they have been cheated on their purchase of the ailing refrigerator, "They got the biggest ads of any of them!" - as if brand name recognition, the size and quantity of the advertising, guaranteed the quality of the product. ${ }^{54}$ Willy's allusions, likewise, to the clichés of advice books on how to succeed in business with their undertone of anxiety - "I'm not dressing to advantage, maybe," and, "It's not what you say, it's how you say it - because personality always wins the day" - require that cultural context of 'how to' manuals and self-marketing, against which to judge the irony. Similarly, to a culture as yet unfamiliar with many of the more negative consequences of urban growth Willy's complaint that the street where he lives is now "lined with cars" - as against the time in his youth when the house stood alone on the city's edge - might well be misunderstood as a reactionary rant against exciting social progress. ${ }^{55}$

Some aspects of Miller's commentary on the free market system, however, carry powerfully in any language. Linda's indignant words after Willy is sacked - "He works for a company thirty six years in March, opens up unheard of territories to their trademark, and 
now in his old age they take his salary away!" - is a case in point. ${ }^{56}$ Even if we assume Linda is exaggerating out of wifely loyalty, her protest against the casual discarding of a loyal employee - one she dearly loves resonates powerfully. So does Willy's own protest: “I put thirty-four years into this firm. Howard, and now I can't pay my insurance! You can't eat the orange and throw the peel away - a man is not a piece of fruit!",57 The pathos of Charley's summary of the life of the salesman in his epitaph on Willy is equally moving: "a man way out there in the blue, riding on a smile and a shoeshine. And when they start not smiling back that's an earthquake. And then you get yourself a couple of spots on your hat, and you're finished." It would surely evoke a vision of the tenuous existence of the Willy Lomans of the world, even for those accustomed to basic economic security. ${ }^{58}$

In seeking to bridge whatever cultural chasms might open up between the play and its Chinese audiences, Ying Ruocheng in his role as the translator of Death of a Salesman was invaluable to Miller, not least in his creative transpositions of English figures of speech into Chinese. He found telling equivalents for the colourful figurative language that fills the original text. 
When Willy talks about his anger at a fellow salesman's insulting epithet, "walrus" - which would mean nothing in Chinese - Ying translated the insult, "barrel of oil." In Willy's admiring description of Ben - "That man was a genius, that man was success incarnate" - the expression "success incarnate" was translated with a phrase that Ying told Miller combined ideas of "heaven-sent" with those of "success", and a satiric allusion to "making a buck" - all appropriate to Bens' character. Howard's "Business is business," as he refuses to help Willy - who desperately reminds Howard of the old family-like friendship with his father- was appropriately rendered, "Kin is kin, money is money," Miller gave Ying Ruocheng, no doubt deservedly, a great deal of credit for the success of the Beijing production of his play - noting that the audience laughed at the jokes. ${ }^{59}$

Another concern was the play's - for China radical form. Ying Ruocheng assured Miller that some novel elements, such as the flashbacks to Willy's past, the scenes of fantasy enacted on a stage apron that comes to represent a projection of Willy's mind, would have been somewhat prepared for through recent exposure to foreign films and television. ${ }^{60}$ A more 
daunting potential cultural barrier, Miller anticipated, would be the way in which Chinese theatre-goers for several decades had been trained to approach a play almost wholly in terms of a reductive quest for the work's "message". Moreover, the few plays to which they had been exposed in recent years had tended to present characters in stark terms of heroes and villains, with little psychological subtlety. Learning to understand this context, Miller noted in the diary he kept throughout the rehearsals in Beijing, gave him an enhanced understanding of what the play meant to Ying Ruocheng and his colleagues:

Salesman is a hammer to knock apart the formula, and in saying this I see it now as they do. For Willy is indeed a social product, while his autonomy as a person remains intact, and this can drive the dialecticians crazy. ${ }^{61}$

Further misunderstanding was to arise over what might at first glance seem a minor matter - the question of makeup. Chinese actors were accustomed to play Western roles with wigs and whiteface, and in any role to make up heavily. As Miller explains: 
Makeup is a mask here, not an emphasis of the expressiveness of the face. The stage is an artificial place where ordinary-looking people have no business. On the other hand, if layers of masking are permitted to turn the actors into symbols ... rather than fully dimensional realistic people, they will be defeating their own attempts to act with, rather than against, reality.

It took the playwright-as-director some time, and a good deal of debate, to persuade the actors to dispense with the layers of white makeup usually regarded as indispensable to playing Europeans. The cast were equally appalled at Miller's insistence that most of the roles should be played without wigs: "A Chinese play without wigs - you might as well send on the actors without clothes!"62 In the event, the decision to present the actors as recognisably Chinese - "the Lomans as Chinese-looking-people," and to set the play in a world that was neither definitely China nor definitely the United States was justified by the play's effect on the audience. "It made us feel more like them,' "remarked one audience member - meaning, in effect, more like Westerners. Miller took this and similar observations as a hopeful sign that this pioneering production of Death of a Salesman could pave the way for world theatre in 
China, as an experience with which Chinese people could readily identify. ${ }^{63}$

As the production's director, Miller wrestled endlessly with the Chinese love of over-dramatic acting, a style which might have its place in traditional opera, but was, as he no doubt correctly believed, inappropriate in a contemporary play observing the conventions of realism. On this subject the author, who normally is fair-minded to the point of generosity when commenting on actors' performances in other people's productions, is merciless:

A remark that might call for a smile causes its hearer to laugh; a mild chuckle becomes a guffaw accompanied by deep appreciative nods. What should be a wave of recognition to an acquaintance turns into a bang of the palm on his back and plenty of ha-ha-ha thrown in. There is also the tendency to start a speech facing right or left to whoever is supposed to be hearing it, ending with the speaker sliding around until he is facing the audience, whose departure the Chinese actor seems to fear is imminent. ${ }^{64}$

The entire Chinese approach to acting, Miller noted, was in any case radically different from that of Westerners: 
By virtue of training and temperament the Chinese actor creates feeling by acknowledging his debt to his objectifying techniques. He does not 'throw himself into the part' but builds a performance by pieces of knowledge, as it were, of story, character, and specific circumstances. He doesn't start with frenzy but hopes to end with it.

Such an approach was not 'wrong', Miller conceded - merely different. He retained great hopes for his cast: "If the actors tend to err on the side of calculation I suspect that given enough performances they will come around to the spontaneity that finally justifies everything." ${ }^{65}$ What Miller did appreciate was the actors' thorough attention to detail, their quick memories, their searching questioning to gain the fullest possible understanding of their respective roles.

All the same, he grew frustrated at times by a Biff whose performance constantly threatened to become larger than life, and by a theatrical stereotype of the devoted wife and mother that at first painfully constrained the potential of the gifted actress Zhu Lin, who was playing Linda. Instead of playing Linda as a strong character, "the woman on whom Willy relies," as Miller puts it, she at first interpreted the role, he 
complained, as a pitiful figure, "a lachrymose fount." In this dramatic tradition, he noted in his diary, "Crying is what Mothers are for." (The sentimental interpretation reminded him, the playwright added, of the early silent movies, and of the melodramatic Yiddish theatre of his youth in Brooklyn.). ${ }^{66}$ Once, however, she grasped the essential strength of Linda's character, Zhu Lin, an actress with a distinguished reputation nationwide, apparently gave a fine performance:

The restraint, the purity of her concept of the woman, the valor of Linda and her anguish - everything comes together so simply, with such restrained elegaic lyricism, that I cannot help gasping. ${ }^{67}$

It is easy to smile at the Chinese actress' initial misreading of the role of Linda as "a lachrymose fount," until we recall that some Western feminist critics more familiar than Zhu Lin with Western cultural assumptions have made a similar misjudgement of the character of Linda. According to this perspective, Linda is merely the typical midtwentieth century American housewife, whose life revolves around her home and family, with her slavish obedience to the dictates of advertising and her dogged loyalty to her man. ${ }^{68}$ She $i$ s all of the above, but a great 
deal more besides. Above all, she is far from passive in defence of her family. It is Linda who strives to shake her sons out of their selfish indifference to their father's emotional crisis; who alerts Biff to the sinister meaning of the piece of rubber piping under the stairs and has him remove and hide it; who berates her sons for their callous selfishness in deserting their father in the hour of his distress to go off with women; who discusses and plans, urges and encourages her husband to seek a practical way out of the impasse his job has become. ${ }^{69}$ In 'Salesman' in Beijing Miller elaborates on his conception of Linda for the benefit of the Chinese cast, in a way that suggests his own vision of the character is far from that of a helplessly hand-wringing bystander. In the process he gives the Western reader a powerful insight into his original conception of his character:

She has strength, she has held this family together and she knows this very well. She has the intelligence to run a large office, if that had been her fate. She knows the contribution she has made ... I tell how Linda has gone with Willy on some of his winter trips, sitting beside him in the little car to keep him company. How she has walked miles to pay the gas and electric bills and save the postage. 'She is determined, not simpering. ${ }^{, 70}$ 
Detailed examination of the representation of motives and relationships in the text of Death of a Salesman constantly opened new vistas of cultural difference, provoking lively discussion between actors and director. The actor playing Biff commented on the scene between himself and his brother Happy as they lie awake in their beds in their father's house, that he couldn't imagine a Chinese person "continuing to talk to his brother once he says, as Biff does, that he is going to sleep." This was not a matter of courtesy, the actor emphasised, but of a pragmatic attitude to life, a willingness to accept a situation as given. It would be pointless to go on talking if Happy had decided not to listen. ${ }^{71}$ The actor playing Charley was concerned about the credibility of his character's generosity in repeatedly lending Willy money, and in the end, when Willy is dismissed from his job, offering him employment. He could not believe that anyone would be "so good" to someone else, in a similar situation in the Chinese social context. Chinese history clearly has something to answer for in this case. Miller comments: 
How odd, yet fitting, that in this time and this place, after revolution and civil war and cruelties beyond the mind's power to contain, this Charley should be asking not why everyone is so bad to Willy but why Charley is so good to him. ${ }^{72}$

Miller then offered the actor a possible motive for Charley's kindness to Willy, in the form of "a deep feeling for Linda, whom he greatly admires." This additional suggested motive apparently rendered the character credible for the actor who had to play him, as within the scope of his own cultural experience: "His face lit up then; he could act that.",73

The play's minor female characters raised questions. What the actors were mainly concerned to establish was whether characters like Willy's mistress, Letta and Miss Forsythe are actually prostitutes, and whether they are to be morally disapproved of. Miller allayed the concerns of the actress playing the Woman, Willy's mistress, by saying that she is not a prostitute, but "a lonely woman who has a regular office job and is not at all like a prostitute," and that she genuinely likes Willy and his line of gab and his pathos, and so she sees him for dinner perhaps twice a month and they talk and 
'behave like husband and wife for a night." "Great relief on all sides," the playwright reported. ${ }^{74}$

One element in Death of a Salesman the actors found it easy to relate to was the theme of father-son relationships, so integral to the play. As Miller remarked of Chinese reactions to his text, "The story of Salesman may be moving and interesting to them, not for any adverse reflections on American society but for its family relations, in which they see their own."

The father-son theme is developed, with multiple variations, throughout the text, beginning with Willy's relationship to father figures in his life. Willy's insecurity, like his incurable romanticism and surrender to illusion, is given credible grounding in his own lack of a father, that he compensates for by the weaving of romantic legends. As Willy says to Ben, reaching out for the security of a father figure, "Father left when I was such a baby and I never had a chance to talk to him and I still feel - kind of temporary about myself." ${ }^{, 76}$ Thus he invents and invokes the myth of an adventurous pioneering father, hero and role model: "My father lived many years in Alaska. He was an adventurous man. We've got quite a little streak of selfreliance in our family." ${ }^{\text {77 }}$ Even Ben is a kind of 
surrogate role model / parent for Willy, presenting an imaginary ideal of capitalist success that Willy can never hope to attain. Willy's pain at being dismissed from his job is compounded by hurt paternal pride where his young boss is concerned. As he exclaims, "That snotnose. Imagine that? I named him. I named him Howard." The claim highlights the impertinence and condescension of the role reversal in the young boss Howard repeatedly addressing Willy, an employee twice his age, as "kid": "But where am I going to put you, kid?"78 Finally, Willy's lifelong aspirations for, misunderstandings of, and disillusionment with, his own two sons, permeate the play:

It was not difficult for the Chinese actors to identify with Willy Loman's ambitions for his sons - or even to understand Willy's indulgent attitude to Biff's dishonesty and petty thieving - although they were somewhat perplexed about how they should identify with a 'hero' who openly admits he wanted his son's schoolfriend to help his son cheat in the graduation exam: "You mean to say Bernard wouldn't give you the answers?"79

The cast described as "very Chinese" the way Willy urges his sons to strive for success. "'The Chinese 
father also wants his sons to be dragons," one of them said, meaning that he wants them "to compete and excel over others." Ying Ruocheng, reflecting on how he should play the role of Willy, in Willy's relationship with his older son, saw the generation gap, the mingled love and hostility between Willy and Biff - culminating, after fights and betrayals in Willy's cry of astonished gratitude: "Biff - he likes me!" - as "absolutely Chinese. $" 80$

Where they encountered a cultural obstacle to understanding a character's motivation, members of the cast were invited to examine Chinese culture for parallels. When for instance the actors had difficulty in grasping exactly what Happy considers so inappropriate about his brother Biff's whistling in the lift at his place of work - "You don't raise a guy to a responsible position who whistles in the elevator!" Miller invited the actor playing Happy to imagine a young Party official standing waiting for transport with a group of colleagues, who "is off by himself whistling a tune," while the rest are "trying to stand there looking businesslike and responsible": 
This seemed to strike a note; he nodded deeply, an excited look on his face - such behavior would indeed seem a little crazy - and he at once delivered the speeches with a better mix of admonitory indignation and self-satisfaction with his own sanity and social discipline.

Finding difficulty in identifying with Willy's legend of Dave Singleman, who had "drummed merchandise in thirty-one states" and was still making his living as a salesman at the age of eighty-four "without ever leaving his room." up with the analogy of the armed escorts in old China, who protected goods wagons on long journeys. The idea of these men, who had "a certain mythology about themselves, a camaraderie that set them apart," and who, not unlike Willy Loman, found themselves useless and unwanted, once the days of the wagon caravans ended, gave Ying the inspiration he needed. Once Ying had this insight, as Miller noted in his diary, "I have the feeling that he no longer feels himself above Willy, perhaps because he has truly felt a certain nobility in his suffering ... " ${ }^{83}$ When Ying found it hard to quite believe in Willy's obstinate deafness to Biff's account of how he has failed in his attempt to get a loan from Oliver, Miller suggested an analogy from recent Chinese history. What if Willy's blind faith in his son, 
in the face of all the evidence, had something in common with the blind faith of the Chinese people in Mao and the Cultural Revolution? Ying Ruocheng took the point immediately. "IIt's as Chinese as hell,", he said. The actor laughed. "We're always doing that finding some hope where there really isn't any. It's our whole history." "\$4 The analogy between the Willy-Biff relationship and the frustrated feelings of love and resentment evoked by the authoritarian father figure of Mao tse Tung had a further resonance for the cast, relating also to the play's theme of generational conflict. "By politicizing the Willy-Biff conflict, I think, I have brought the play into their time and made it more familiar, perhaps more Chinese," Miller noted in his diary. ${ }^{85}$

The combined creative intelligence of author and cast, combined with their painstaking dedication, had their reward on the first night of performance in Beijing. As Miller wrote it up in his diary, the audience is passionate. At the end they would never stop applauding. Nobody left. When he was taking his bows, I thought I saw a tremendous serious victory in the look on Ying Ruocheng's face. The gamble had paid off, the Chinese audience had understood Salesman and was showing its pride in the company. 
"The job of culture," Miller remarks, at the close of 'Salesman' in Beijing, "is not to further fortify people against contamination by other cultures but to mediate between them from the heart's common ground." ${ }^{87}$ The Chinese, emerging from the recent paranoia of the Cultural Revolution, identified with the themes of the Crucible. They found resonances in Death of a Salesman, likewise, not only because their society in the 1980s was making the bewildering and often painful transition between state ownership and free- market capitalism, but because so much in the representation of the Lomans' family relationships had its resonance in their own lives. As Miller wrote of his Beijing cast, "If they are making the Lomans ultimately comprehensible to their fellow Chinese it is because they have found the Lomans in themselves." ${ }^{\prime 88}$

We began with Miller's complaint that his plays were more appreciated by audiences abroad than in his native land. With the standing ovation in Beijing we may well conclude that his work has truly met with full comprehension only now that he belongs to the world. 


\section{Notes}

1 Timebends: A Life. 1987. London: Methuen, 1988, p.534.

2 All references to the primary texts in the present study are to the Methuen edition of Miller's plays, (London, 2000.)

3 "The American theatre is five blocks long, by about one and a half blocks wide." Quoted in June Schlueter, "Miller in the Eighties," in Christopher Bigsby (ed.), The Cambridge Companion to Arthur Miller. 1997. Cambridge University Press, 2006, p.154.

4 Timebends, pp. 315-6.

5 p.244.

${ }^{6}$ See Matthew C. Roudané, "Death of a Salesman and the Poetics of Arthur Miller," in Bigsby, Companion, pp.60-85.

7 Timebends, p.137.

${ }^{8}$ It was left to a sociologist, writing twenty years later, to argue that Miller's plays in general, and Death of a Salesman in particular, offer useful social critique. See Paul Blumberg, "Sociology and Social Literature: Work Alienation in the Plays of Arthur Miller," American Quarterly 21 (1969): pp.291-310.

In the 1980s Michael Spindler published an illuminating study, "Consumer Man in Crisis: Arthur Miller's Death of a Salesman," in his American Literature and Social Change: William Dean Howells to Arthur Miller. Bloomington: Indiana University Press, 1983. A decade later John S. Shockley explored the motifs of salesman, actor and politician, drawing telling parallels between the career of Willy Loman and that of Ronald Reagan. In "Death of a Salesman and American Leadership: Life Imitates Art," Journal of American Culture 17 (1994): pp.49-56.

9 Eleanor Clark, “Death of a Salesman," Partisan Review, June 1949, p.632.

${ }^{10}$ A number of academic critics continued the negative trend well into the late 1960s. Typical in this respect is Eric Mottram, in "Arthur Miller: The Death of a Political Dramatist in America," where Mottram argues that Miller offers a shallow and simplistic view of social issues. In John Russell Brown and Bernard Harris (eds.), American Theatre. New York: St Martin's Press, 1967: pp. 23-58.

${ }^{11}$ Stephen Barker, "Critic, criticism, critics. In Bigsby, Companion, pp.23044.

12 For two early discussions of affinities between Death of a Salesman and classic tragedy, see Ester Merle Jackson, "Death of a Salesman: Tragic Myth in the Modern Theatre." CLA Journal 7 (1963): pp. 63-76; and B. S. Field Jr., "Hamartia in Death of a Salesman,* Twentieth Century Literature 18 (1972): pp.79-84. 
13 An early critic who recognised and explored this tragic dimension in Miller's work is Robert Hogan, who contends that the essential significance of the plays lies precisely in this tragic dimension. Arthur Miller. Minneapolis: University of Minnesota Press, 1964.

${ }^{14}$ Steven R. Centola, Arthur Miller in Conversation. Dallas: Contemporary Research Associates, 1993, p.54.

${ }^{15}$ A point endorsed and elaborated on by Enoch Brater in his biographical study, Arthur Miller: A Playwright's Life and Works. London: Thames and Hudson, 2005: pp.51-53.

${ }^{16}$ Arthur Miller, "The Shadows of the Gods," in Robert A. Martin (ed.), The Theater Essays of Arthur Miller. New York: Penguin, 1978, p.179; also Miller's critical study of the playwright, "Ibsen and the Drama of Today." In James McFarland (ed.), The Cambridge Companion to Ibsen. Cambridge: Cambridge University Press, 1994: p.232.

${ }^{17}$ For a thoughtful analysis of Miller's affinities with, and debt to, Ibsen see Thomas P. Adler, "Conscience and Community in An Enemy of the People and The Crucible" (1997). In Bigsby, Companion, pp.86-100.

${ }^{18}$ In Mark Lamos, “An Afternoon with Arthur Miller." American Theatre 3 (1986): p.21.

19 Critics have debated to what extent Miller's version of Puritan New England corresponds to any probable historical actuality - most notably in a critique by a veteran historian of that period, Edmund Morgan, who considers that Miller's image of Puritan society is fundamentally misconceived. (Edmund S. Morgan, "Arthur Miller and the Salem Witch Trials: A Historian's View." In John Wallace (ed.), The Golden and Brazen World: Papers in Literature and History, 1650-1800. Berkeley: University of California Press, 1985: pp.171-86.) Miller himself, as if anticipating such objections, prefaces his play with the caveat, "This play is not history in the sense in which the word is used by the academic historian." He goes on to point out the alterations he has made for the sake of artistic licence - cutting down the number of judges mentioned in the historical record, raising the age of Abigail to make probable the fictional incident of her brief affair with Procter, and so on. (The Crucible, p.124.)

${ }^{20}$ Quoted in Bigsby (ed.), Arthur Miller and Company. London: Methuen, 1990, p.189.

${ }^{21}$ At times Miller's plays were capable of provoking controversy in Europe also. It proved impossible, for instance, to find a French producer to make a film of Incident at Vichy, owing to producers' unwillingness to deal with the play's controversial theme of French collaboration with the Nazis. Timebends, p.540.

22 Timebends, p.184. 
23 Bigsby, "Introduction" to Companion, p.3. For a powerful personal account of Miller's researches at Salem, and the genesis of the play, see also Timebends, pp. 334-7.

${ }^{24}$ The actual première took place in Wilmington, Delaware, where the play was more positively received than in New York.

25 Timebends, p.347.

${ }^{26}$ In an ironic modern echo of the plot of his play Miller refused to denounce co-workers in the left-wing theatrical circles of his youth, and was sentenced to a year's imprisonment (a sentence later quashed on appeal).

${ }^{27}$ p.350.

${ }^{28}$ Timebends, p.341

${ }^{29}$ In Timebends Miller writes, “Jean-Paul Sartre's screenplay ... seemed to me to lay an arbitrary Marxist mesh over the story that led to a few absurdities. Sartre laid the witchcraft outbreak to a struggle between rich and poor peasants, but in reality victims like Rebecca Nurse were of the class of relatively large landowners, and the Proctors and their like were by no means poor." p.349.

${ }^{30}$ pp. 347-8.

31 p.348.

${ }^{32}$ Michael Billington, The Guardian, 5 February 2008.

33 Richard Eyre, The Guardian, 16 March 2002.

34 Timebends, p.540.

35 Brenda Murphy, Miller: Death of a Salesman. Cambridge University Press, 1995, p.70.

36 Matthew C. Roudané, "An Interview with Arthur Miller." In Roudané (ed.), Conversations with Arthur Miller. Jackson: University Press of Mississippi, 1987: pp.360-61.

37 Inge Morath and Arthur Miller, In Russia. London: Secker and Warburg, 1969: p. 31. Morath's contribution to the book is the collection of evocative photographs that accompanies Miller's text.

38 pp.38-9.

39 p.41.

40 p.62.

${ }^{41}$ pp. 41-43.

42 Timebends, pp. 569-70. 
43 Matthew C. Roudané, "Death of a Salesman." In Bigsby, Companion, pp.77-78.

44 p.77.

45 Timebends, p.570.

46 Inge Morath and Arthur Miller, Chnese Encounters. 1979. Harmondsworth: Penguin, 1981, p.9.

47 p.106.

48 Timebends, pp. 185-6.

49 Arthur Miller, 'Salesman' in Beijing. 1984. London: Methuen, 1991.

50 p.130.

51 p.15.

52 p.86.

53 p.134.

54 p.148.

${ }^{55}$ Death of a Salesman, p.135.

56 p.163.

57 p.181.

58 pp. 221-2.

59 pp. 162, 241, 240.

60 'Salesman' in Beijing, p.23.

${ }^{61}$ p. 204.

${ }^{62}$ pp. 186, 207.

${ }^{63}$ pp.172, 233.

${ }^{64}$ Chinese Encounters, p.95.

${ }^{65}$ p.251.

66 'Salesman' in Beijing, p.43.

${ }^{67}$ p.79.

${ }^{68}$ See, for instance, Carol Billman, "Women and the Family in American Drama," who views Linda as a marginalised figure in a patriarchal world. Arizona Quarterly 36.1 (1980), pp.35-48.

${ }^{69}$ Death of a Salesman, pp. 210-11, p.165, p.133.

${ }^{70}$ Salesman' in Beijing, p.69. 
${ }^{71}$ p. 20.

72 p. 23.

${ }^{73}$ p.50.

${ }^{74}$ p.24.

${ }^{75}$ p.131.

${ }^{76}$ p.159.

${ }^{77}$ p. 180.

${ }^{78}$ Death of a Salesman, pp.180, 192.

${ }^{79}$ p.206.

80 'Salesman' in Beijing, pp.7-8, 132, 218.

${ }^{81}$ pp. 104-5.

${ }^{82}$ Death of a Salesman, p.180.

83 'Salesman' in Beijing, pp. 174-5.

${ }^{84}$ pp. 60-61.

${ }^{85}$ p.80.

${ }^{86}$ pp. 251-2.

${ }^{87}$ pp.249-50.

${ }^{88}$ p.249. 